\title{
Bio Gas from Textile Cotton Waste - An Alternate Fuel for Diesel Engines
}

\author{
C. Sundar Raj ${ }^{*}, 1$, S. Arul $^{2}$, S. Sendilvelan ${ }^{3}$ and C.G. Saravanan ${ }^{4}$ \\ ${ }^{I} M G R$ Educational and Research Institute, MGR University, Chennai; Department of Mechanical Engineering, \\ Bharathiyar College of Engineering and Technology, Karaikal, Pondicherry 609 609, India \\ ${ }^{2}$ Panimalar College of Engineering, Chennai, India \\ ${ }^{3} M G R$ Educational and Research Institute, Chennai, India \\ ${ }^{4}$ Department of Mechanical Engineering, Annamalai University, India.
}

\begin{abstract}
Methane was generated from cotton waste, while considering its pollution in textile industries. Cotton waste includes solid content and is rich in cellulose having a moisture content of $8.8 \%$. It is difficult to form slurry as the waste float on water and hence an experimental set up has been made like a batch type digester and experiments were conducted with a different proposition of water with or without addition of seeding materials. It was found that cotton waste with 5 to $7.5 \%$ seeding material like cow dung or pig dung at temperatures of 30 to $35^{\circ} \mathrm{C}$ generated bio gas continuously, with a reasonably high yield from the tenth day after feeding. The gas contained rich methane and was tested in a single cylinder diesel engine as a dual fuel had the tendency to save $60 \%$ of diesel.
\end{abstract}

Keywords: Cotton waste, anaerobic digestion, biogas, methane, alternate fuel.

\section{INTRODUCTION}

Shortage of conventional liquid fuels and alarming rate of emissions from the internal combustion engines and subsequent environmental pollution have generated interests in the development of new alternatives for petroleum fuels. Bio gas appears to be a promising fuel for cooking, lighting, running vehicles and power generation, etc. It can directly be used in Spark Ignition Engines as an alternate fuel. Although replacing diesel fuel entirely by biogas is very difficult, an increased interest has emerged for the use of biogas, with different amounts and different techniques in diesel engines as a dual fuel operation in recent years [1]. Biogas is produced when certain bacteria decompose biological matter, in an anaerobic environment, known as anaerobic digestion (AD). It is about $20 \%$ lighter than atmospheric air and has an ignition temperature in the range of $650^{\circ} \mathrm{C}$ to $750^{\circ} \mathrm{C}$. It is an odorless and colorless gas that burns with clear blue flame similar to that of Liquefied Petroleum Gas and burns with $60 \%$ efficiency in a conventional biogas stove [2]. It has a specific gravity of 0.55 in relation to air and its fuel value is directly proportional to the amount of methane [3]. There are different types of bio gas plants such as Khadi, Pragati design, Ganesh Ferro cement digester. These are continuous feeding type digesters using biogas manure, sewage sludge, municipal solid waste, biodegradable waste as feed stock. The basic gas producing reaction in these digesters is $2 \mathrm{C}+2 \mathrm{H}_{2} \mathrm{O}=\mathrm{CH}_{4}+\mathrm{CO}_{2}$ [4]. Any material having cellulose as one of its constituents may be used to produce bio gas. India is one of the countries having a large number of textile industries and also having one of the largest cattle populations

*Address correspondence to this author at the Department of Mechanical Engineering, Bharathiyar College of Engineering and Technology, Karaikal, Pondicherry 609 609, India; E-mail: csundarraj@yahoo.com in the world. The problem of the final scrap from textile industries has now assumed serious dimensions, since it has no salability and pollutes the atmosphere. If these types of waste are not degraded, they get accumulated and occupy space and lead to infectious diseases, attract pests and spread foul odor in the environment. The country consumes cotton fibers approximately 26 million tons per year, of which approximately 0.21 million tons of cotton waste is generated during yarn manufacture. At present this waste is not put into any use except to some extent, as compost for cultivating some vegetables. Mostly, it is disposed off by burning. This may increase the $\mathrm{CO}_{2}$ level in the atmosphere and also pollutes the surrounding areas. This powder waste also leads to the growth of harmful bacteria, which induce allergic reaction in human. Cotton waste is of high solid powder content and is rich in cellulose. The results for analyses of cotton waste by SITRA (South India Textile Research Association) are given in Table 1.

Table 1. Contents of Cotton Waste

\begin{tabular}{|c|c|}
\hline Contents & Percentage \\
\hline \hline Moisture & 8.80 \\
\hline Ash \% by weight & 7.20 \\
\hline Ether extractive & 12.00 \\
\hline Non-cellulose & 16.00 \\
\hline Cellulose & 54.00 \\
\hline Nitrogen & 0.80 \\
\hline Metals \& other & 3.20 \\
\hline
\end{tabular}

The technological options for the utilizations of cotton waste at the spinning mills are: 
1. To generate biogas as an additional source of energy and manure and

2. To convert the digested slurry into biomanure by incorporating recycling larva/grubs.

In this work, it was found that five kilograms of cotton waste could generate about 200 liters of biogas in 50 days. It is advantageous for the mills to use their non-salable cotton waste, which is in perennial supply for biogas generation at their premises itself. Normally bio gas is produced either by batch type or continuous type digesters. In this work, batch type digesters are used because the scum is a mixture of coarse fibrous material and it acts as an insulator.

Since cotton waste contains more than $52 \%$ of cellulose, high water retention capacity, sufficient carbon-to-nitrogen ratios and low heavy metal content and hence it could be economically converted into biogas and manure. Also, it contains around $70 \%$ solid content whereas other raw materials like cow dung which has only 15 to $18 \%$. Cotton waste requires cleaning and some retention time after mixing with water to convert in to slurry, before loading in the digester.

\section{EXPERIMENTAL SETUP}

Biogas digester used for this process is a fixed batch type. It consists of a container with a rigidly fixed lid with a provision for gas outlet. It is sealed completely to prevent leakage. The process layout is shown in Fig. (1).

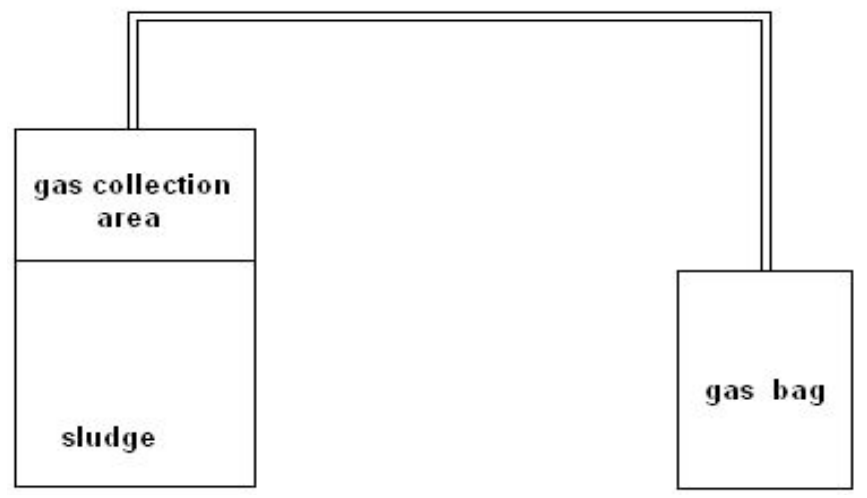

Fig. (1). Layout of bio gas production.

\section{SAMPLE ANALYSIS}

Five-kilogram of cotton waste with different seeding material are taken in the specially made digesters as in Fig. (2) to generate biogas. Material to water ratio is determined by the nature of the biomass in respect of its moisture content, density, ambient temperature, $\mathrm{pH}$, etc. Excess water may reduce the concentration of biomass in digester and also reduce the volume available for gas collection.

After pre treatment of cotton waste, it is mixed with water in the ratio of 1:2 along with different proportions of seeding material are allowed for fermentation for ten days. Generation of biogas begins from the fifth day and the yield is continuous from the tenth day onwards as the fermentation starts slow in the initial stages and become active after 10 days. It was found that the reaction reduces after 25 days for a stock of $5 \mathrm{~kg}$ of cotton waste and nearly comes to an end after 45 days as shown in Table 6 and Fig. (4). The anaerobic digestion depends on temperature; as the bacteria (Mesophile) is active between 30 to $38^{\circ} \mathrm{C}$ and thermopile bacteria over $55^{\circ} \mathrm{C}$, percentage of seeding material, type of seeding material and percentage of moisture [5].

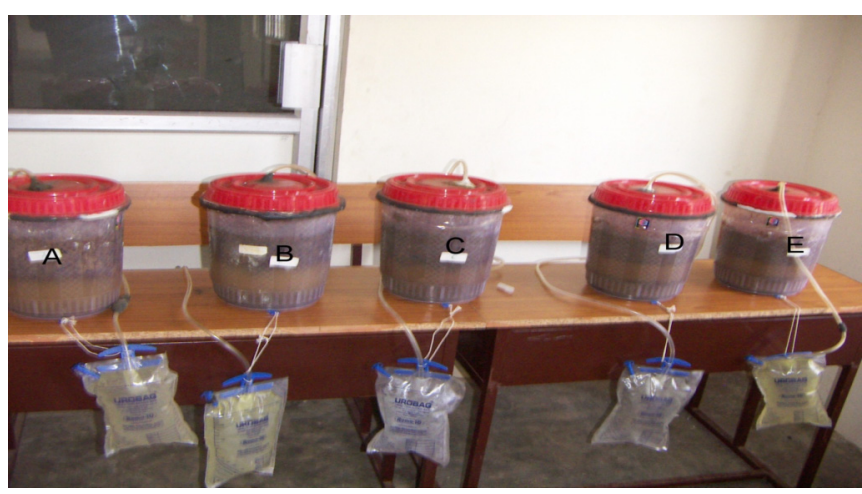

Fig. (2). Bio gas production setup - Photograph.

Experiments were conducted for $2.5 \%, 5 \%, 7.5 \%, 10 \%$ and $15 \%$ of seeding material at various temperatures for biogas production. The different seeding materials used are cow dung, pig dung and goat waste. The effect of seed and temperature are represented in Figs. $(\mathbf{3}, \mathbf{5})$ respectively. The outlet gas is tested at CPCL (Chennai Petroleum Corporation Limited) with Gas Chromatography as specified in Table 2 and the values are tabulated from Tables 3-7.

Table 2. Specifications of Gas Chromatography

\begin{tabular}{|c|c|l|}
\hline SI.No & Details & \multicolumn{1}{c|}{ Specifications } \\
\hline \hline 1 & Instrument used & Gas Chromatography, FISONS, Italy \\
\hline 2 & Column & Packed \\
\hline 3 & Packing material & Porapak Q $80 / 100$ \\
\hline 4 & Test Conditions & $\begin{array}{l}\text { Column temperature: } 30^{\circ} \mathrm{C}-200^{\circ} \mathrm{C} \\
\text { Detector temperature: } 150^{\circ} \mathrm{C} \\
\text { Detector used: HWD }(H o t \text { wise detector) } \\
\text { Sample quantity: } 0.5 \mathrm{ml} \\
\text { Sampling mode: Auto sampler }\end{array}$ \\
\hline 5 & Carrier gas used & Helium \\
\hline
\end{tabular}

Table 3. Bio Gas Productions Using Cow Dung as Seeding

\begin{tabular}{|c|c|c|c|c|c|c|c|}
\hline \multirow{3}{*}{ S1. No } & \multirow{5}{*}{ Constituents } & \multicolumn{5}{|c|}{$\begin{array}{c}\text { Ratio of Seeding Material } \\
\text { (Cow Dung) with Cotton Waste }\end{array}$} \\
\cline { 3 - 8 } & & $\mathbf{0 \%}$ & $\mathbf{2 . 5 \%}$ & $\mathbf{5 \%}$ & $\mathbf{7 . 5 \%}$ & $\mathbf{1 0 \%}$ & $\mathbf{1 5 \%}$ \\
\hline \hline 1 & $\mathrm{CH}_{4}$ & 25 & 55 & 70 & 77 & 77.1 & 77.5 \\
\hline 2 & $\mathrm{CO}_{2}$ & 67 & 40.85 & 26.75 & 19.8 & 19.57 & 19.3 \\
\hline 3 & $\mathrm{~N}_{2} / \mathrm{Air}$ & 8 & 4.15 & 3.25 & 3.20 & 3.33 & 3.20 \\
\hline
\end{tabular}

\section{PERFORMANCE EVALUATION IN DIESEL ENGINE}

Experiments were conducted on a single cylinder computerized diesel engine test rig with the specifications shown in Table 8. The bio gas is admitted through a venturi as in Fig. (6) and T joint as in Fig. (7) at air inlet for proper mixing [6]. The experimental setup is shown in Fig. (9) and the results are compared. 
Table 4. Bio Gas Production Using Pig Dung as Seeding

\begin{tabular}{|c|c|c|c|c|c|c|}
\hline \multirow{2}{*}{ Sl. No } & \multirow{2}{*}{ Constituents } & \multicolumn{5}{|c|}{$\begin{array}{c}\text { Ratio of Seeding Material } \\
\text { (Pig Dung) with Cotton Waste }\end{array}$} \\
\cline { 3 - 7 } & & $\mathbf{2 . 5 \%}$ & $\mathbf{5 \%}$ & $\mathbf{7 . 5 \%}$ & $\mathbf{1 0 \%}$ & $\mathbf{1 5 \%}$ \\
\hline \hline 1 & $\mathrm{CH}_{4}$ & 60 & 72 & 77.5 & 77.8 & 78 \\
\hline 2 & $\mathrm{CO}_{2}$ & 36 & 24.85 & 19.3 & 18.99 & 19.05 \\
\hline 3 & $\mathrm{~N}_{2} / \mathrm{Air}$ & 4.00 & 3.15 & 3.20 & 3.31 & 2.95 \\
\hline
\end{tabular}

Table 5. Bio Gas Production Using Goat Dung as Seeding

\begin{tabular}{|c|c|c|c|c|c|c|}
\hline \multirow{2}{*}{ SI. No } & \multirow{2}{*}{ Constituents } & \multicolumn{5}{|c|}{$\begin{array}{c}\text { Ratio of Seeding Material } \\
\text { (Goat Dung) with Cotton Waste }\end{array}$} \\
\cline { 3 - 7 } & & $\mathbf{2 . 5 \%}$ & $\mathbf{5 \%}$ & $\mathbf{7 . 5 \%}$ & $\mathbf{1 0 \%}$ & $\mathbf{1 5 \%}$ \\
\hline \hline 1 & $\mathrm{CH}_{4}$ & 50 & 65 & 68 & 68 & 68.2 \\
\hline 2 & $\mathrm{CO}_{2}$ & 45.8 & 31.65 & 28.7 & 28.75 & 28.6 \\
\hline 3 & $\mathrm{~N}_{2} / \mathrm{Air}$ & 4.2 & 3.35 & 3.30 & 3.25 & 3.20 \\
\hline
\end{tabular}

Table 6. Bio Gas Production at Different Temperatures for 5\% Seeding (Cow Dung)

\begin{tabular}{|c|c|c|c|c|c|c|}
\hline Sl. No & Constituents & $\mathbf{2 5}^{\mathbf{C}} \mathbf{C}$ & $\mathbf{2 7}^{\mathbf{0}} \mathbf{C}$ & $\mathbf{3 0}^{\mathbf{0}} \mathbf{C}$ & $\mathbf{3 2}^{\mathbf{0}} \mathbf{C}$ & $\mathbf{3 5}^{\mathbf{0}} \mathbf{C}$ \\
\hline \hline 1 & $\mathrm{CH}_{4}$ & 52 & 60.5 & 77 & 77.5 & 78.6 \\
\hline 2 & $\mathrm{CO}_{2}$ & 44.5 & 36.25 & 19.8 & 19.25 & 18.15 \\
\hline 3 & $\mathrm{~N}_{2} /$ Air & 3.5 & 3.25 & 3.2 & 3.25 & 3.25 \\
\hline
\end{tabular}

Table 7. Bio Gas Production Rate for 5\% Seeding (Cow Dung) at Ambient Temperature

\begin{tabular}{|c|c|c|}
\hline SI. No & Duration & $\begin{array}{c}\text { Volume of Gas Collected/5kg of } \\
\text { Cotton Waste in Liters }\end{array}$ \\
\hline \hline 1 & 5 to 10 days & 10 \\
\hline 2 & 11 to 15 days & 25 \\
\hline 3 & 16 to 20 days & 30 \\
\hline 4 & 21 to 25 days & 35 \\
\hline 5 & 26 to 30 days & 30 \\
\hline 6 & 31 to 35 days & 25 \\
\hline 7 & 36 to 40 days & 22 \\
\hline 8 & 41 to 45 days & 8 \\
\hline 9 & 46 to 50 days & 10 \\
\hline
\end{tabular}

Bio Gas Production with respect to Seeding material

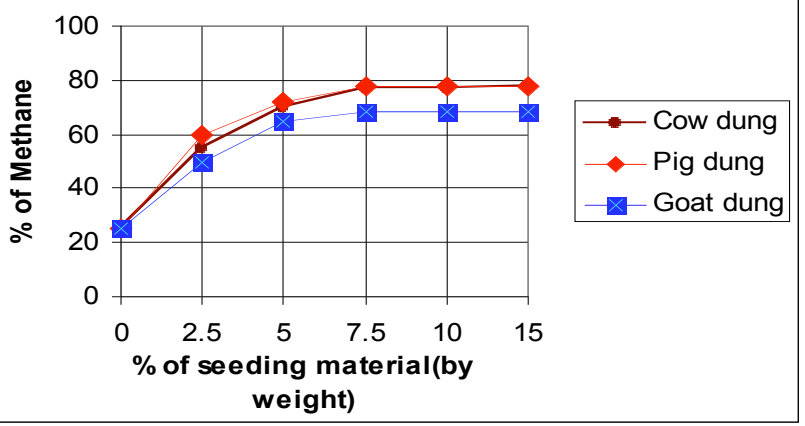

Fig. (3). Effect of gas production with seeding.

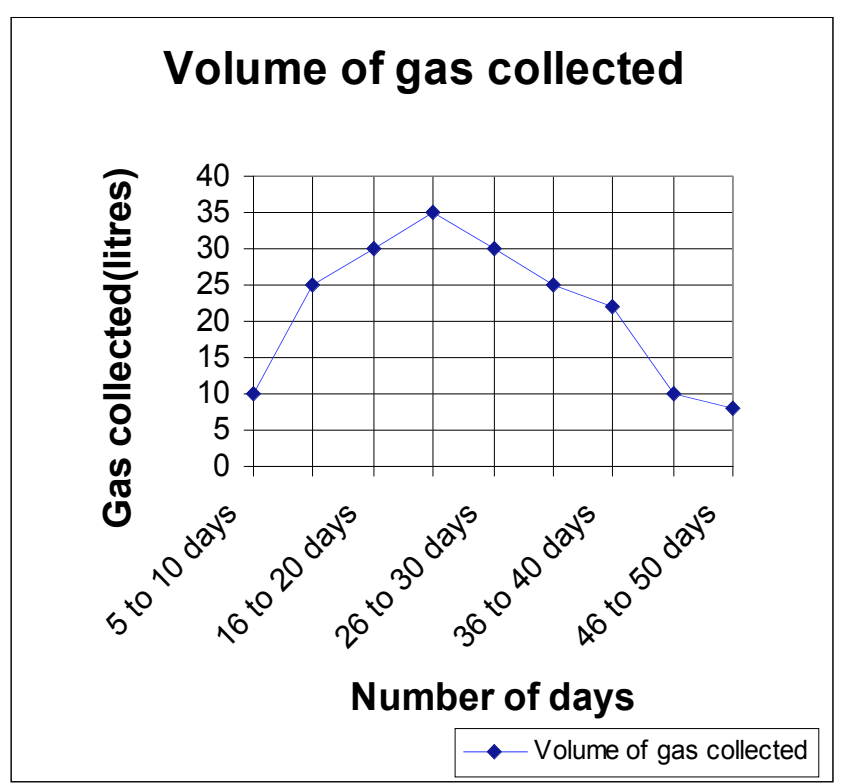

Fig. (4). Volume of gas collected for 5\% seeding.

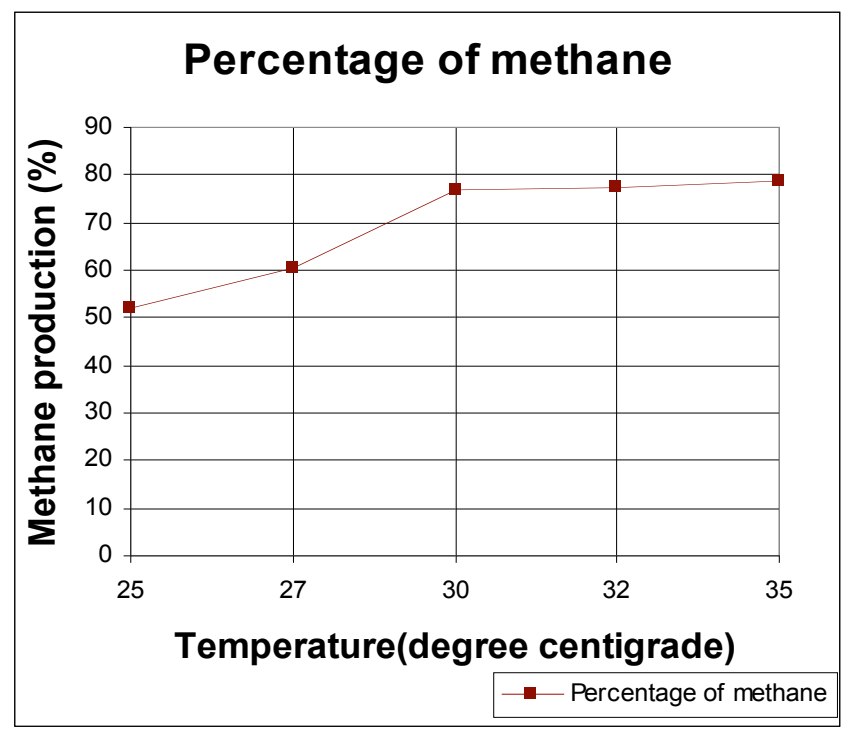

Fig. (5). Effect of temperature on methane formation. 
Table 8. Specifications of the Engine

\begin{tabular}{|l|l|}
\hline General Details & Four stroke, Single cylinder, Water cooled \\
\hline Bore & $87.5 \mathrm{~mm}$ \\
\hline Stroke & $110 \mathrm{~mm}$ \\
\hline Compression ratio & $17.5: 1$ \\
\hline Rated output & $5.2 \mathrm{kw} @ 1500 \mathrm{rpm}$ \\
\hline Injection pressure & $200 \mathrm{bar}$ \\
\hline Fuel injection timing & $23^{0} \mathrm{BTDC}$ \\
\hline
\end{tabular}

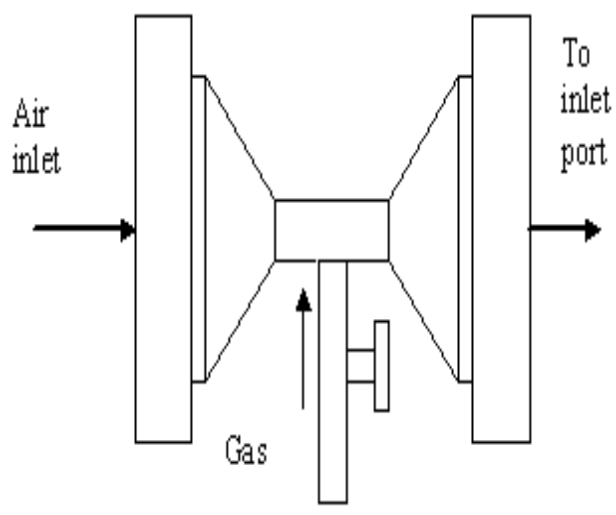

Fig. (6). Venturi attachment.

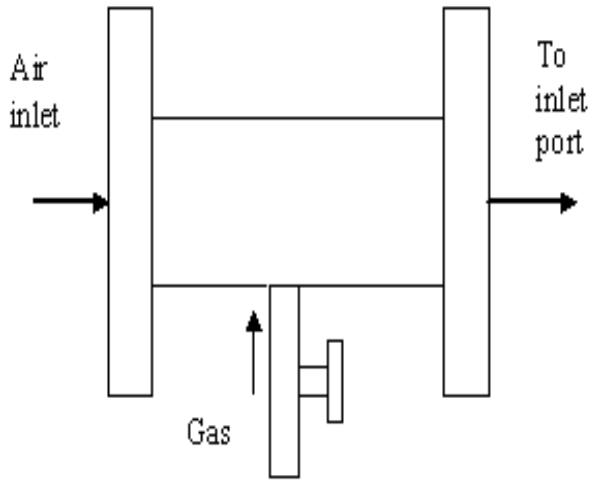

Fig. (7). T joint attachment.

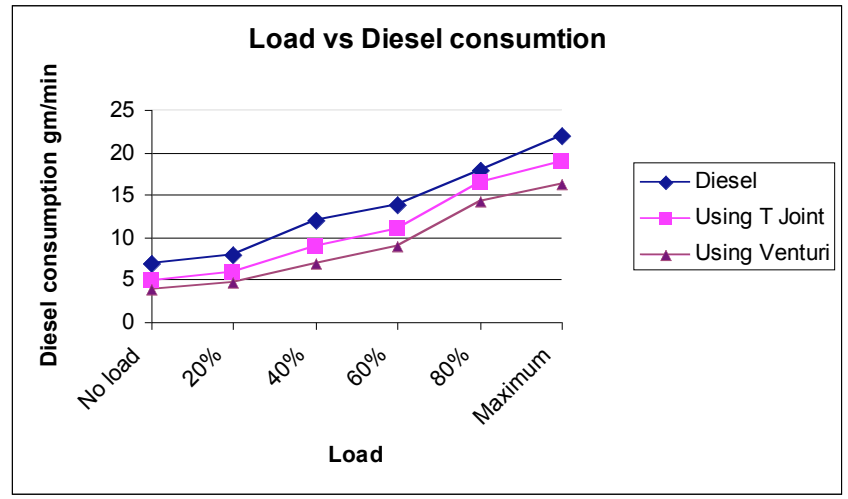

Fig. (8). Diesel saving for different attachments.

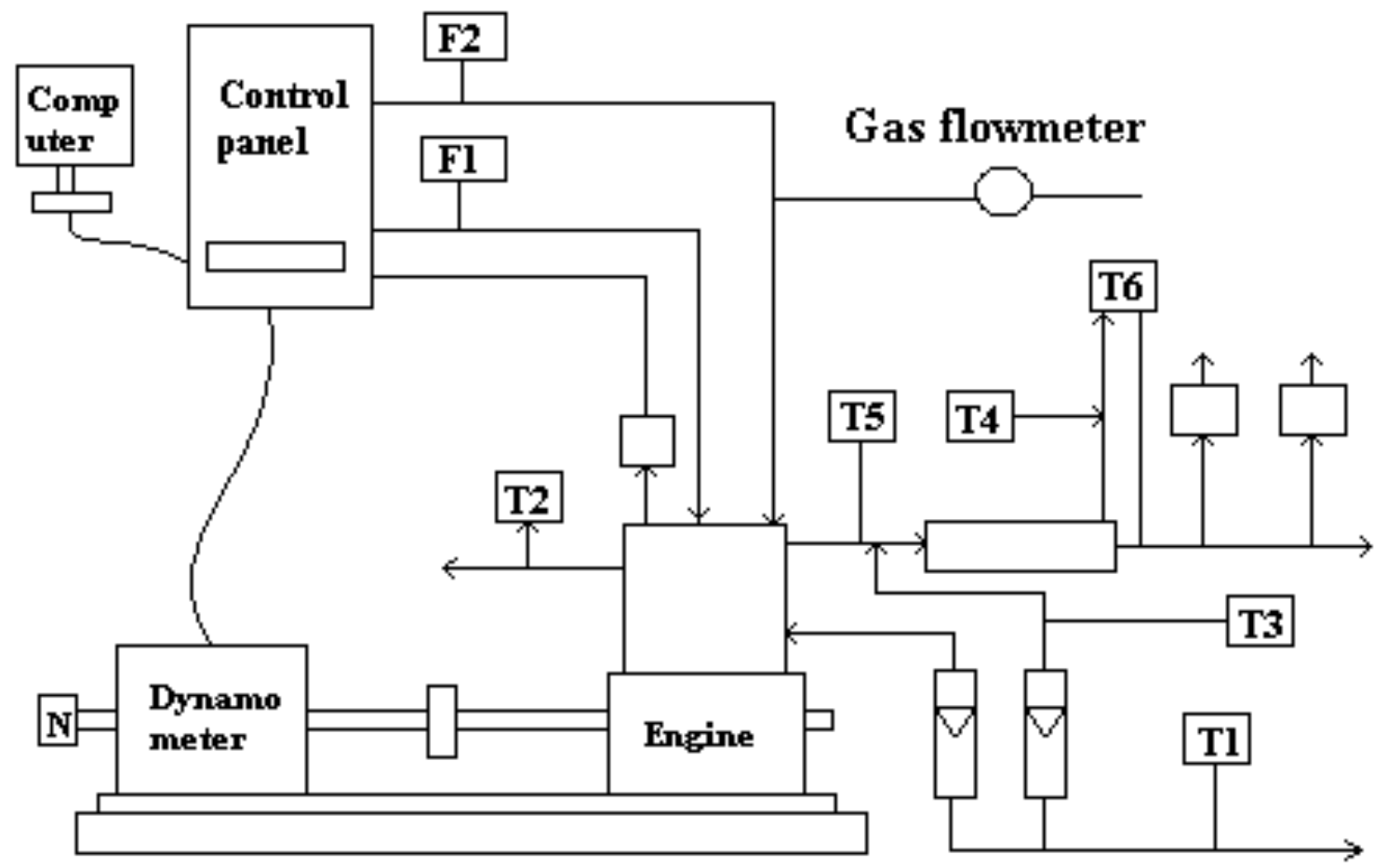

$\mathrm{T} 1 \& \mathrm{~T} 3$ - Inlet water temp ${ }^{\circ} \mathrm{C}$

$\mathrm{T} 2$ - Outlet engine water temp ${ }^{\circ} \mathrm{C}$

$\mathrm{T} 4$ - Outlet calorimeter water temp ${ }^{\circ} \mathrm{C}$

T5 - Exhaust gas temp ${ }^{\circ} \mathrm{C}$ before calorimeter
T6 - Exhaust gas temp ${ }^{\circ} \mathrm{C}$ after calorimeter

$\mathrm{N}$ - RPM decoder

F1 - Fuel flow differential weight unit

F2 - Air flow differential velocity unit

Fig. (9). Experimental setup to analyze diesel consumption. 
It was found from Fig. (8) that venturi attachment saves more diesel than $\mathrm{T}$ joint attachment as the turbulence of the gas air mixture is increased.

\section{CONCLUSIONS}

Generally, in textile mills waste like, fly, raising fly, flat strip, dirty cotton, etc are lifted for open-end yarning and fetches approximate value of INR 5 to $7 /-$ per $\mathrm{kg}$ (USD $1=$ INR 40). Depending on the quality of waste, some grades are not utilized for any purpose. Also, open-end yarning waste that amounts to $10.5 \%$ will have no use and degraded by the way of burning. The problem of cotton waste has now assumed serious dimensions, since it pollutes the atmosphere. Spinning mills may be in the advantageous position to utilize the biogas, which can be produced in their premises to avoid the problem of pollution. From the experimental results it was found that:

- Cotton waste can efficiently be used as potential resource for biogas generation if proper conditions are maintained.

- $\quad$ Biogas production from cotton waste can be increased with cow dung, pig dung and goat dung as seeding material.

- 5 to $7.5 \%$ of cow or pig dung with cotton waste by weight generates around $77 \%$ of methane against $60 \%$ in other techniques and thereby increases the volumetric calorific value.

- The production rate is high from $15^{\text {th }}$ day to $30^{\text {th }}$ day after starting fermentation
- The optimum temperature for gas production is found to be 30 to $32^{\circ} \mathrm{C}$.

- $\quad$ Around $60 \%$ of diesel can be saved by using biogas as dual fuel, but more work to be made on the control of emission and performance of combustion.

- $\quad$ From the experimental study, it is clear that the use of venturi at the inlet port of the engine is effective method to supply the bio gas.

- The bottled biogas can be used as a dual fuel in CI engine fitted automobiles to reduce fossil fuel consumption

\section{REFERENCES}

[1] L. JohnFry, "Methane Digesters for Fuel Gas and Fertilizer", L. John Fry Richard Merrill 1973, [Online]. Available: www.journeytoforever.org/biofuel library/methane digesters

[2] Khadi and Village Industries Commission and its non conventional energy programmes, "Non conventional energy programme under kvic,” KVIC, Bombay, India 1993.

[3] W. Kossmann, and U. Pönitz, "Bio gas digest volume - 1" ISAT [Online]. Available: www.gtz.de/de/dokumente/en-biogas-volume1

[4] V. Balasubramanian, K. Sridhara, and V. Ganesan, "Performance evaluation of small agriculture engine operating on dual fuel(Diesel + Natural gas) system" SAE international, 951777, September 1995.

[5] Bhatia and Ramesh, "Diffusion of Renewable Energy Technology in developing countries- A case study of bio gas engines in India", world development, vol. 18, pp. 575-590, April 1990.

[6] S. S. Satpulately, and D. B. Zodpe, "Performance evaluation of Dual Fuel Engine used for Power Generation", proceedings of the $19^{\text {th }}$ national conference on IC Engines and combustion, 2005, pp. 499-503. 